arrangement and scale of fees were agreed upon for the administration of an ophthalmic benefit.

The President told the meeting that he had already received assurance, from a body of medical men skilled in refraction work in London, that they were prepared to carry out such work there, and would do so for members of Approved Societies at a reduced fee.

Representatives from the following towns: Bristol; Birmingham, Glasgow, Leeds, Manchester, and Wolverhampton, who were present at the meeting, stated that in their districts they considered similar provision could be made. It was pointed out by some of the speakers, that if provision could be made for refraction work in this way, great relief would be afforded to the at present over-crowded out-patient departments in hospitals.

Finally, the following resolution, proposed by Mr. Harrison Butler, and seconded by Mr. Clegg, was agreed to :

"That this meeting of ophthalmic surgeons considers that there are sufficient numbers of medical practitioners competent to carry out ophthalmic work in connection with the Approved Societies, and approves of the line of action which is being adopted by the Council of British Ophthalmologists in the matter with the Ministry of Health."

The meeting further requested the Council to confer with the Ophthalmic Committee of the British Medical Association, which also has the subject under consideration.

\title{
ANNOTATION
}

\section{Miners' Nystagmus and the Compensation Act}

A lengthy letter on this subject was published in the British Medical Journal of March 23, 1924, over the signature of $\mathrm{Mr}$. A. S. Percival of Newcastle-upon-Tyne.

Mr. Percival has had a long experience in one of the most important coal mining areas of this country and his views on the matter cannot be overlooked. The object of these remarks is not "to take coals to Newcastle," but to open a correspondence in this journal, in order to place our readers in possession of the opinions of all ophthalmic surgeons who have special knowledge of the disease, for outside the mining districts, ophthalmic surgeons see very few examples of this condition.

Mr. Percival has been indefatigable in collecting and tabulating information; thus, in the British Medical Journal (May 8, 1923) he gave statistical evidence based on the condition of 43,684 under- 
ground workers in his district which "conclusively demonstrated that in the two Northern Circuits, deficiency of light was not the essential factor in the production of nystagmus." He found that electric light is the sole illuminant used at the Plenmeller Pit and at the South Moor Colliery. In the former of these "in 1922 nearly 4.3 per cent. acquired the disease among the hewers, and 1.3 per cent. among the non-hewers-that is the percentage of hewers affected was 4.7 times greater, and that of non-hewers was 5.5 times greater where electric lamps only were used." At the latter colliery " twenty-five years ago electric lamps were used solely and the percentage of their nystagmus cases was notoriously high; but on abolishing electric lamps and installing oil safety lamps, they had no cases of nystagmus among the non-hewers and hardly any among the hewers."

$\mathrm{Mr}$. Percival insists that any pitman who has once had nystagmus from which he recovers after a period of rest followed by surface work will most certainly have a recurrence if he ever returns to hewing. It is his firm belief that "a certain percentage, say four or five per cent. of all children, has a predisposition to the disease at birth; if this idiosyncrasy is absent, they will never acquire nystagmus, but if they have this predisposition, they have it for life." "The Workmen's Compensation Act," he says, "is fundamentally unjust as far as nystagmus is concerned. Practically it means that the patient receives whole or part compensation for the rest of his life; for there are few workmen who are wise enough to seek other employment."

If a workman has acquired nystagmus it shows, in Mr. Percival's opinion, that he is unfit for coal hewing. He suggests that a nystagmus patient who reports himself within six weeks of his first noticing symptoms, should after examination and corroboration by an independent referee, who is really familiar with the disease, immediately be given a liberal compensation payable fortnightly for a period not exceeding one year, in order to give him time to recover and learn some other trade. "Special consideration should be given to those who acquire the disease late in life, as they will find it harder to get new employment." But, before compensation is given the workman must sign a declaration that he will never seek employment at a colliery again, this declaration being kept and filed by the colliery manager. Any workman when first obtaining employment should be examined, a note made of his sight in each eye and any defect recorded on a "health card"; this card to follow the man throughout his working life, and accidents and any disease to be noted on it as they occur.

"The present Compensation Act has done nothing to check the disease. The numbers increase every year." Underground work (hewing) is more profitable than surface work, and the pit villages 
are hotbeds of the disease, a sort of vicious circle being formed from father to son.

Our previous annotations on miners' nystagmus dealt with the First and Second Reports of the Committee and will be found in Vol. VI, p. 262 and Vol. VIII, p. 63.

For our own part we think that the evidence in favour of the now generally accepted theory of the fundamental causation of miners' nystagmus in deficient illumination at the pit face is overwhelming, but we are equally of opinion that there is a strong psycho-neurotic element which has not yet received sufficient attention, even by the Miners' Nystagmus Committee itself. There can be little doubt that it is this factor which is essentially responsible for the enormous expenditure in compensation.

Whether Mr. Percival's opinion that the surest way of checking the increase of the disease lies in clearing out the pit villages of all predisposed to nystagmus is or is not correct, it seems hardly practicable at the present time, when unemployment is rampant in all trades and in the face of so much industrial distress throughout the country.

\section{ABSTRACTS}

\section{I. -DEVELOPMENT}

(1) Lo Cascio, Dr. G. (Rome).-The development of the sheath of the optic nerve in man. (Lo sviluppo delle guaine del nervo ottico nell'uomo.) Annal. di Ottal., Nov.-Dec., 1923.

(1) Lo Cascio begins his paper with a critical review of the work of previous observers, notably that of Falchi and Seefelder. A useful bibliography accompanies the paper. He has himself examined some thirty embryos, the earliest of which had a length of $26 \mathrm{~mm}$., as well as numerous infantile and adult eyes. Methods of staining were those of Mallory, Calleja and van Gieson.

His conclusions are as follow :

The development of the sheath of the optic nerve begins at the end of the first half of the third month of intrauterine life, at which time there is already obvious indication of the sclera.

In embryos at the beginning of the third month $(28.8 \mathrm{~mm}$.) the optic nerve is imbedded in the mesoblast contained in the orbital muscular cone, without any indication of the differentiation of that tissue which is the prelude to the formation of the sheath of the optic nerve.

The first indication of a sheath to the optic nerve is found in embryos of $38 \mathrm{~mm}$., in which, in correspondence with the angle 